Augustin Kossi N. AoudjI ${ }^{1}$ Armand Sèdami Igor YêvidÉ ${ }^{1}$ Jean Cossi GANGLO ${ }^{1}$ Gilbert ATINDOGBÉ ${ }^{1}$ Mireille S. ToYI ${ }^{1}$

Charles DE CANNIÈre ${ }^{2}$ Anathase Hessou Azontond É$^{3}$ Victor ADJAKIDJE ${ }^{4}$ Bruno DE FOUCAULT ${ }^{5}$ Brice A. SINSIN ${ }^{1}$

${ }^{1}$ Faculté des sciences agronomiques Université d'Abomey-Calavi Département d'aménagement et gestion de l'environnement 01 BP 526, Cotonou République du Bénin

2 Université libre de Bruxelles 50 avenue Franklin Roosevelt 1000 Bruxelles

Belgique

${ }^{3}$ Institut national des recherches agricoles du Bénin

01 BP 884, recette principale

Cotonou

République du Bénin

4 Faculté des sciences et techniques

Université d'Abomey-Calavi 01 BP 526, Cotonou République du Bénin

${ }^{5}$ Faculty of Pharmaceutic and Biological Sciences Départment of Botany BP 83

59006 Lille Cedex

France

\section{Structural characteristics and forest sites indentification
Pahou forest reserve, South-Benin and forest sites indentification
in Pahou forest reserve, South-Benin}

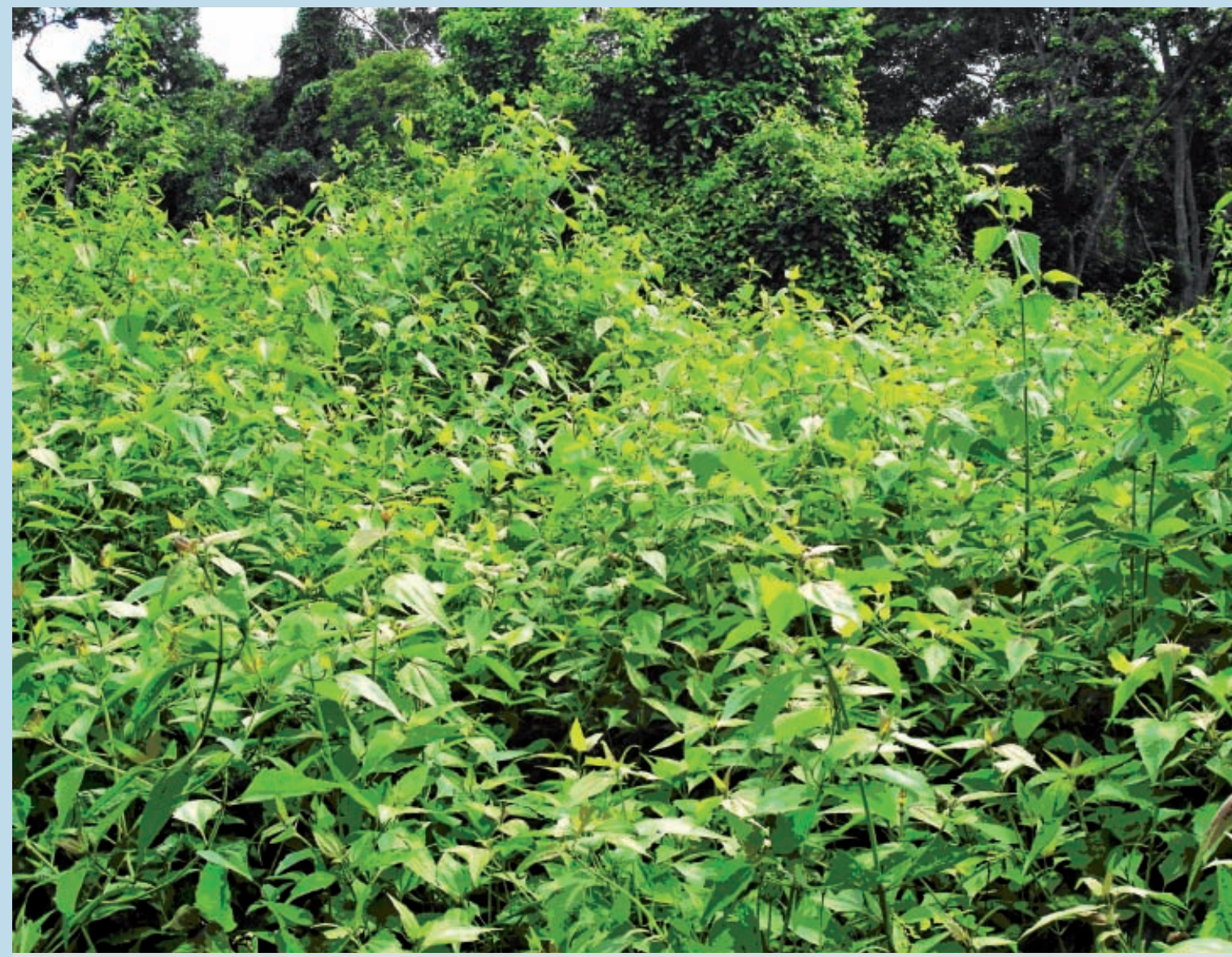

Photograph 1.

Chromolaena odorata and Triumfetta pentandra plant community.

Photograph J. C. Ganglo. 
RÉSUMÉ

\section{CARACTÉRISTIQUES STRUCTURELLES ET IDENTIFICATION DES STATIONS FORESTIÈRES DANS LA RÉSERVE FORESTIÈRE DE PAHOU, AU SUD DU BÉNIN}

L'étude phytosociologique de la forêt classée de Pahou au Sud du Bénin a été réalisée dans une perspective de gestion durable. L'évaluation des communautés végétales a été menée suivant une approche de phytosociologie synusiale intégrée. Les sols ont été caractérisés d'après leurs profils pédologiques et leurs propriétés physico-chimiques. Les paramètres sylvicoles ont été collectés au sein de placettes temporaires, chacune de $300 \mathrm{~m}^{2}$ de surface, installées au sein de sites représentatifs de la forêt. Cette étude a permis d'identifier et de décrire cinq phytocénoses (communautés végétales). Deux cent quarante-sept (247) espèces de plantes ont été inventoriées dans le sous-bois des plantations d'Acacia auriculiformis de la forêt de Pahou ; elles appartiennent à deux cent neuf (209) genres et soixante et onze (71) familles. Les accroissements moyens annuels en diamètre et en hauteur variaient respectivement de 1,2 à $3,1 \mathrm{~cm} /$ an et 1,4 à 4,2 m/an. Ces résultats ont montré que les plantations d'acacias de Pahou sont parmi les plus productives d'Afrique de l'Ouest. Les relations entre les facteurs écologiques et la productivité des différentes communautés végétales, ont permis d'identifier et de cartographier quatre types de forêts dont la plus productive est représentée par la communauté végétale Barteria nigritana et Rauvolfia vomitoria et la moins productive par la communauté à Axonopus compressus et Scleria depressa. Des recommandations ont été faites pour utiliser ces indicateurs phytosociologiques en tant qu'outils de gestion durable de la forêt.

Mots clés: phytosociologie, biodiversité, dendrométrie, synusie, Bénin.

\section{ABSTRACT}

\section{STRUCTURAL CHARACTERISTICS AND FOREST SITES INDENTIFICATION IN PAHOU FOREST RESERVE, SOUTH-BENIN}

The study was carried out in the Pahou forest reserve in southern Benin as a contribution to sustainable management of this forest. Plant communities' assessment was made using the synusial approach to phytosociology. Soils were characterized according to their pedological profiles and physico-chemical properties. Silvicultural plantations parameters were studied using temporary sample plots of $300 \mathrm{~m}^{2}$ each in representative sites of the forest. This study allowed to identify and to describe five phytocoenoses (plant communities). Two hundred and forty-seven (247) species were found in the undergrowth of Acacia auriculiformis plantations in Pahou forest belonging to two hundred and nine (209) genera and seventy-one (71) families. The mean annual increment in diameter and height of the plantations ranged from 1.2 to $3.1 \mathrm{~cm} /$ year and 1.4 to $4.2 \mathrm{~m} /$ year, respectively, indicating that acacias plantings of Pahou forest are among the most productive in West Africa. The relationships between ecological factors and productivity of the different plant communities enabled to identify and map four forest types among which the most productive was represented by the Barteria nigritana - Rauvolfia vomitoria plant community, while the least productive is the biotope supporting Axonopus compressus - Scleria depressa plant community. Recommendations are given on the use of these phytosociological indicators as tools for sustainable forestry management.

Keywords: phytosociology, biodiversity, dendrometry, synusia, Benin.

\section{RESUMEN}

\section{CARARACTERÍSTICAS ESTRUCTURALES E IDENTIFICACIÓN DE ESTACIONES FORESTALES EN LA RESERVA FORESTAL DE PAHOU EN EL SUR DE BENÍN}

El estudio fitosociológico del bosque protegido de Pahou en el sur de Benín, se llevó a cabo enfocándolo al manejo sostenible. La evaluación de las comunidades vegetales se realizó mediante un análisis de la fitosociología sinusial integrada. Se caraterizó los suelos en base al perfíl edafológico y su naturaleza fisicoquímica. Los parámetros selvícolas se cosecharon en parcelas de muestreo temporales, de $300 \mathrm{~m}^{2}$ cada una, establecidas en sitios representativos del bosque. Este estudio ha permitido identificar y describir cinco fitocenosis (comunidades vegetales). Se inventariaron doscientas cuarenta y siete (247) especies de plantas en el sotobosque de plantaciones de Acacia auriculiformis del bosque de Pahou, perteneciendo a doscientos nueve (209) géneros y setenta y una (71) familias. Los incrementos medios anuales en diámetro y altura variaron respectivamente entre 1.2 a $3.1 \mathrm{~cm} /$ año y 1.4 a $4.2 \mathrm{~m} /$ año. Estos resultados muestran que las plantaciones de acacias de Pahou están entre las más productivas del Africa occidental. Las relaciones entre los factores ecológicos y la productividad de las diversas comunidades vegetales permitieron identificar y cartografiar cuatro estaciones forestales, la más productiva estando representada por la comunidad vegetal de Barteria nigritana y Rauvolfia vomitoria, y la menos productiva siendo la comunidad de Axonopus compressus y Scleria depressa. Se recomienda el uso de estos indicadores fitosociológicos como instrumentos adecuados para el manejo sostenible del bosque.

Palabras clave: fitosociología, biodiversidad, dasonomía, sinusia, Benín. 


\section{Introduction}

The basic objectives of the majority of forest plantation programs in Benin are to address the shortage of natural forest resources in the country, to produce high quality wood and firewood to supply the population's needs and therefore to reduce the pressure on natural forests. Any sustainable management of forest resources must be based on the results of forestry research, especially forest site identification and a sound knowledge of their potentialities and constraints so that appropriate silvicultural techniques can be applied. Among the most planted exotic trees in Benin, Acacia auriculiformis was introduced in the 1980s and since then, has been planted in several parts of the country. Acacia auriculiformis, a fast-growing medium sized tree species (HulikatTI, Madiwalar, 2011), is a leguminous tree of the sub-family of Mimosoidae native to Australia (NorthQueensland), Papua New Guinea and the Moluccas Islands in Indonesia (SAHRI et al., 1998). It can survive on many soil types such as ferralitic soils, ferruginous soils, heavy clayish soils, nutrient poor soils, fertile soils... Apart from the governmental plantations, $A$. auriculiformis is considerably planted by smallholder farmers because of its capacity of soil conservation and useful products, especially poles. Moreover, tables, chairs, and armchairs of Acacia timber wood are more and more found in several parts of Benin. Because of its usefulness, $A$. auriculiformis has been rapidly adopted by planters in the country, and actually, is considered as the second forest species planted in Benin with respect to the planted acreage: about 10,000 hectares (ha). Despite its high importance, $A$. auriculiformis had deserved little interest in research in the country. Indeed in Benin sound research works that can profitably guide silvicultural practices are still lacking. Especially, in Pahou forest reserve where $A$. auriculiformis firewood plantations were established, the prevailing management plan was not based on forest research results, hence, of limited use. It is therefore important to fill research gaps to help for sustainable management of the country's forest resources. Since phytosociology has been introduced in Africa (LEBRUN, 1947), it has been used for various purposes including natural resources management. The study of natural undergrowth of forest plantations was done by many authors to appraise the relationships between undergrowth plant communities, plantation productivity and ecological factors (N'ZALA et al., 1997; Loumeto, 1999; GAnglo et al., 1999; Noumon, GANGlo, 2005; GANGLO, De FoucAult, 2006; AoudJ, GANGLO, 2006). From these studies, clear relationships were established between forest productivity, ecological factors and non-pioneer undergrowth plant communities in particular. Therefore, phytosociology has been shown as a reliable tool for forest management (GANGLO et al., 1999; GANGLO, 2005; GANGLO, De Foucault, 2006). In the light of these findings, the hypothesis was formulated that plantation productivity varies with the biotopes of the undergrowth non-pioneer plant communities so that sustainable management of Pahou forest reserve could be based on the potentialities and constraints of these non-pioneer plant communities.

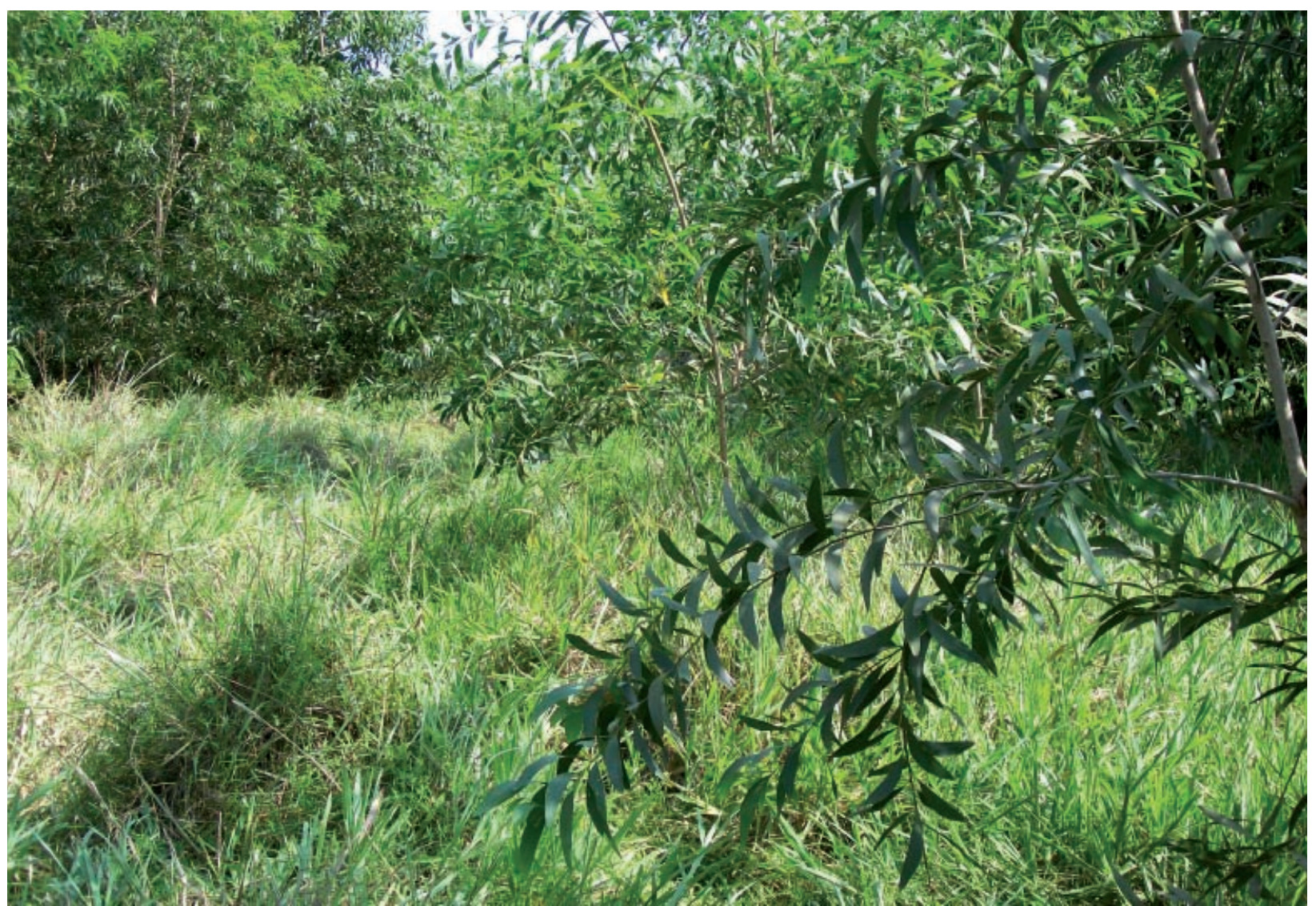

Photograph 2.

Axonopus compressus and Scleria depressa plant community. Photograph J. C. Ganglo. 


\section{Study area}

The study was carried out in Pahou forest reserve (765 hectares) located in South Benin (6 $6^{\circ} 22^{\prime}-6^{\circ} 23^{\prime}$ North lat. and $2^{\circ} 07^{\prime}-2^{\circ} 11^{\prime}$ East long.) (figure 1 ).

From the data we obtained from the ASECNA ${ }^{1}$ in 2006 , our study area was submitted to a subequatorial climate with a mean annual rainfall of 1,100 millimeters in two rainy seasons alternating with two dry seasons. The longest rainy season lasts from March to July whereas the shortest one extended from September to October (figure 2). The mean daily temperature of the area was about $27^{\circ} \mathrm{C}$ with a relative humidity varying from 60 to $95 \%$.

Sandy soils were dominant in the study area. It was composed of sandy strips of variable ages separated by depressions in which wet soils were developed. Ferralitic soils were also found in the study area. In the upper horizons of these soils, sand was dominant (92-97\%); the soil $\mathrm{pH}$ varied from 4.5 to 6.5 , the organic matter content from 0.4 to $3.5 \%$ and $\mathrm{C} / \mathrm{N}$ ratio from 11 to 14 . Cationic exchangeable capacity varied from 3 to $8 \mathrm{meq} / 100 \mathrm{~g}$ of soil with a saturation rate of $33-82 \%$.

The natural vegetation was highly degraded. It was composed of a mixture of coastal forests and Lophira lanceolata savannas. The coastal forest is a semi-deciduous forest dominated by Pycnanthus angolensis, Chrysobalanus icaco var. ellipicus, Manilkara obovata, Syzygium guineense var. littorale, Antiaris toxicaria var. africana, Albizia adianthifolia and A. zygia. Other species of the savannas were Parkia biglobosa, Lannea kerstingii, Anthocleista nobilis, Annona senegalensis, Andropogon gayanus, Andropogon tectorum, Pennisetum polystachion.

Besides natural vegetation, $A$. auriculiformis firewood plantations covered a surface of 520 ha.

\section{Methods}

\section{Phytosociological study of the spontaneous undergrowth vegetation}

To achieve the phytosociological study, a forest map at a 1/10,000 scale was used for orientation in the field and phytocoenoses mapping; a global positioning system (GPS) was used to record relevant points and phytocoenoses contours; Suunto compass was used for field orientation.

In the study of the spontaneous undergrowth vegetation, the synusial approach to phytosociology developed by GILLET et al. (1991) and GILLET (2000) was used. This approach consisted in the description of different levels of vegetation organization so that the synusia was considered as the elementary plant community; the more complex plant communities were combinations of the less complex ones. The plant community was characterized by close relationships between plant organisms in term of competition, complementarities and other features. Such relationships were more effective, efficient and meaningful between plant organisms which shared the same environment, mainly vegetation strata and thus, were close in terms of:

- Morphological types (architectural characteristics);

- Strategy of adaptation (specific strategy of population using optimally environmental resources when one takes into account the endogenous and exogenous constraints);

- Biological types (morphological and physiological adaptations to ecological constraints).

${ }^{1}$ Agence pour la sécurité de la navigation aérienne en Afrique et à Madagascar.

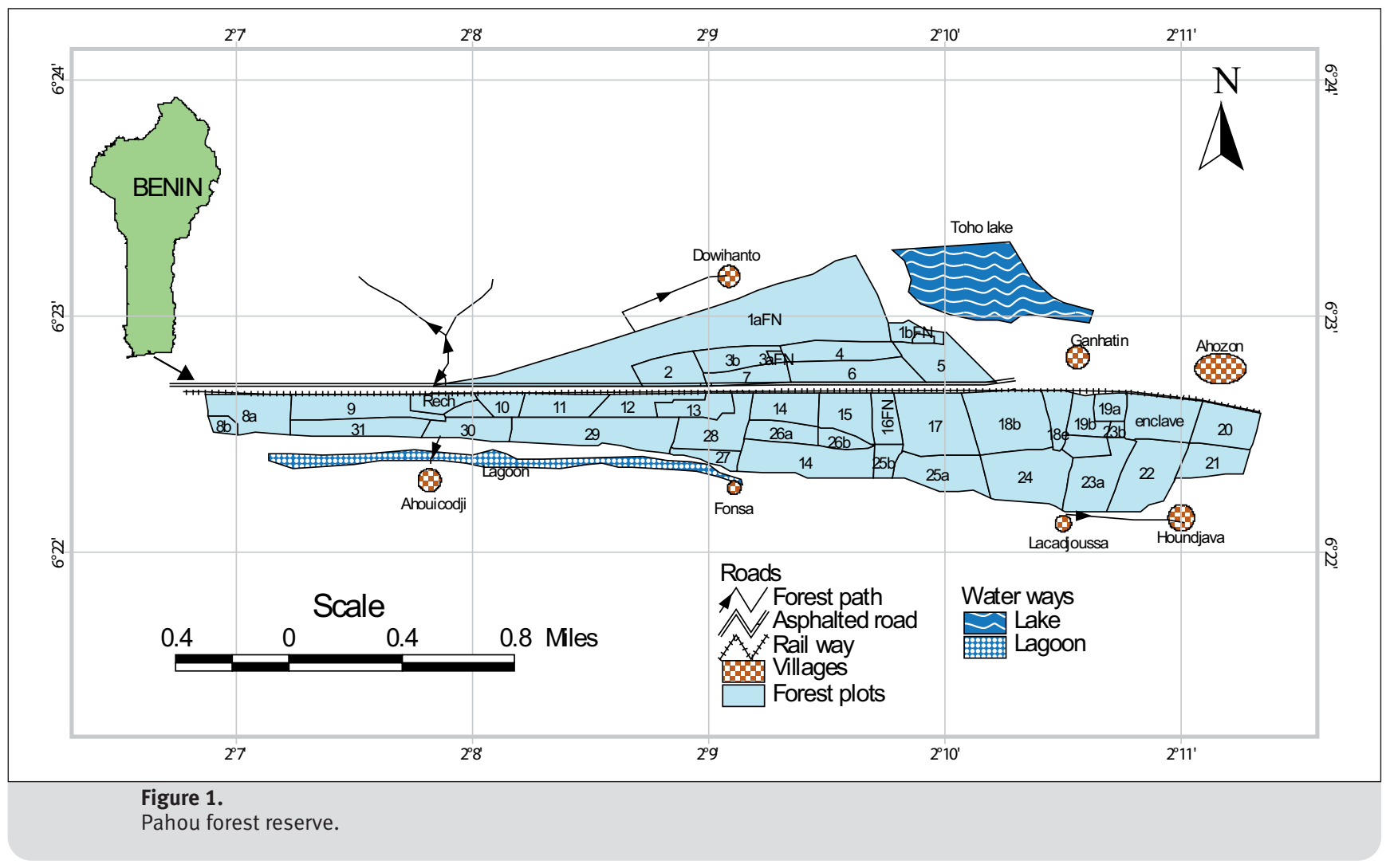


These reasons led to consider the following categories of synusia: annual synusia (composed of annual plant species), low perennialherbaceous synusia, composed of herbaceous species which height was less or equal to 50 centimeters $(\mathrm{cm})$; high perennial-herbaceous synusia, composed of herbaceous species which height exceeded $50 \mathrm{~cm}$; shrubby synusia, composed of non herbaceous species which height was more than $50 \mathrm{~cm}$ and less than or equal to 10 meters (m); liana-synusia and tree-synusia (composed of non-herbaceous species which height was more than $10 \mathrm{~m}$ ). The survey areas varied from 500 square meters $\left(\mathrm{m}^{2}\right)$ in the annual and herbaceous synusia to $1,000 \mathrm{~m}^{2}$ in the other ones. In each survey, all the flowering plant species were recorded. Based on spatial and temporal relationships, plant synusia were combined to describe phytocoenoses. In the absence of spontaneous trees in the plantations, no spontaneous tree-phytocoenoses were observed. Plant species were identified based on the Flora of West Africa (HUTCHINSON, DALZIEL, 1954-1972). The names of taxa were obtained from LEBRUN and STORK (1991-1997).

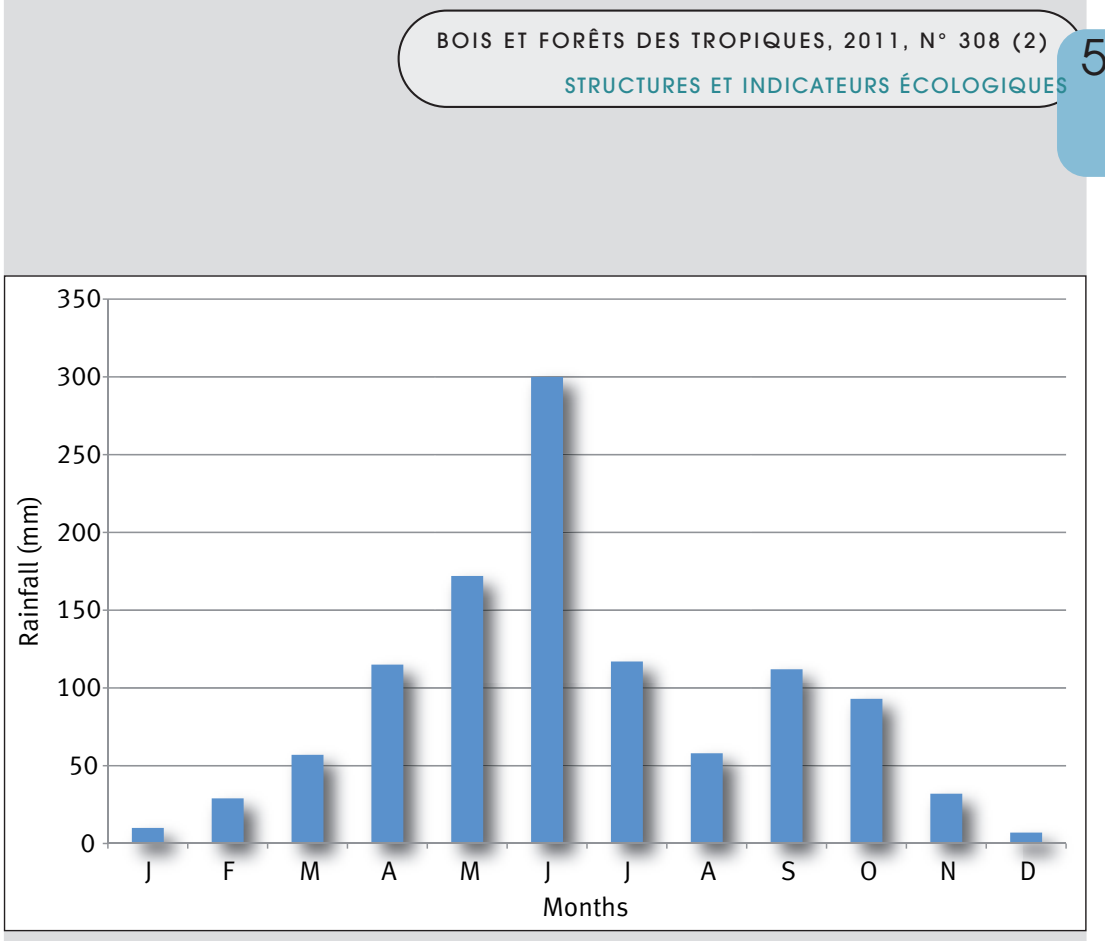

Figure 2.

Rainfall distribution in Pahou region (from 1965 to 2006).

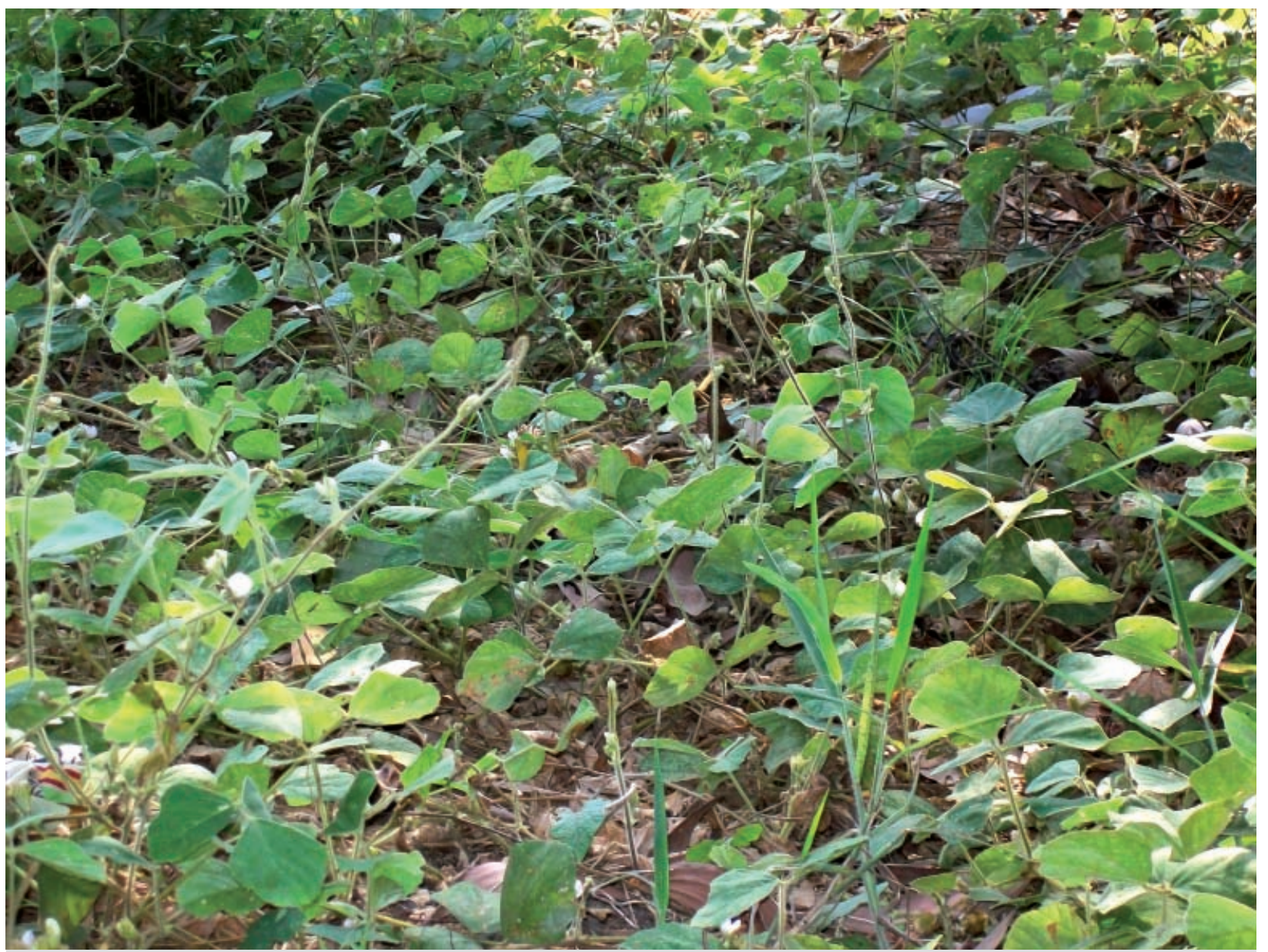

Photograph 3.

Dolichos argenteus and Cassytha filiformis plant community.

Photograph J. C. Ganglo. 


\section{Study of ecological factors and forest plantation parameters}

The study of soils and topography was done according to GANGLo and De Foucault (2006).

The measurements of dendrometric parameters, Diameter at Breast Height id est at $1.30 \mathrm{~m}$ above ground and height $(\mathrm{DBH})$ were achieved by means of tape measure and Blum-Leiss (dendrometer) in at least four rectangular sample plots of $300 \mathrm{~m}^{2}$ each $(15 \mathrm{~m} \times 20 \mathrm{~m})$ chosen in representative parts of each phytocoenose.

The following dendrometric parameters were calculated per plot, and per plantation within plant communities: the mean density of the plantation number of trees per hectare $(\mathrm{N} / \mathrm{ha})$; the mean quadratic diameter $\left(\mathrm{D}_{\mathrm{g}}\right.$ in $\left.\mathrm{cm}\right)$; the mean basal area ( $G$ in $\left.\mathrm{m}^{2} / \mathrm{ha}\right)$. The mean height $(\mathrm{Hg}$ in $\mathrm{m})$ and the dominant height ( $\mathrm{Hd}$ in $\mathrm{m}$ ) being the mean height of the two biggest trees in a plot. The mean annual increments in: diameter (MAID in $\mathrm{cm}$ per year) height (MAIH in $\mathrm{m}$ per year) and dominant height (MAlHd in $\mathrm{m}$ per year).

The Spacing factor [S(\%)] calculated as:

$\mathrm{S}(\%)=\frac{\sum \mathrm{Si}}{\mathrm{np}}$,

where:

- Si (the spacing factor on plot(i)) as:

$\mathrm{Si}(\%)=\frac{\mathrm{ei} \times 100}{\mathrm{Hdi}}$.

- ei (m) (the mean space of trees in plot(i))as:

ei $(m)=\sqrt{\frac{10,000}{n}}$

The productivity levels of plantations within plant communities were estimated by using the site index curves elaborated by MABIALA-MiLongui (2003) for the southern Benin plantations of $A$. auriculiformis. Productivity amplitude was the difference between the lowest and highest values of productivity levels recorded within plant communities. Analyses of variance were performed to evaluate the variation of species diversity and productivity levels according to plant communities, using the NEWMAN-KEULS test to compare the mean productivity and species diversity parameters.

\section{Results}

\section{Ecological and structural characteristics of the undergrowth plant- communities}

The results of our floristic survey allowed us to identify five plant communities whose ecological determinism, structural and dendrometric characteristics were well differentiated as follows: the Chromolaena odorata and Triumfetta pentandra plant community that develops usually in forest's gaps or on the edge of open plantations is adapted to sunlit habitats. This plant community is dominated by the perennial herbaceous synusia of $C$. odorata and $T$. pentandra; the annual synusia of Asystasia gangetica and Phaulopsis angolana; and the low perennial synusia of Mariscus alternifolius and Oldenlandia affinis (photograph 1).

The Axonopus compressus and Scleria depressa plant community was found in temporarily flooded areas of low depression. Slopes were quasi-null in that plant community (mean slope $=1.75 \%$; standard deviation $=0.64$ ). The dominant synusia of this plant community was the perennial herbaceous synusia of $A$. compressus and $S$. depressa (photograph 2).

Besides, Hyptis lanceolata and Spermacoce verticillata annual synusia, was a companion synusia. The basal area of the 1-year-old $A$. auriculiformis plantation within this plantcommunity was low (table I). By contrast, the spacing factor in this relatively dense plantation (density $=1,000$ trees $/$ ha) was exaggeratedly high, showing that, trees were not suffering from competition so far.

The Dolichos argenteus and Cassytha filiformis plant community was found in various topographic positions with low slopes (mean slope $=2.3 \%$; SD $=1.3$ ) and developed in open areas with abundant penetration of sunlight in the undergrowth of forest plantations. The soil texture on the first $50 \mathrm{~cm}$ was dominated by sand. The low perennial herbaceous synusia of $D$. argenteus and $C$. filiformis (photograph 3) was associated with the annual synusia of Mitracarpus villosus and Perotis indica, and the high perennial herbaceous synusia of Andropogon gayanus and Andropogon tectorum. In this 2-year-old plantation A. auriculiformis (density $=926$ trees $/$ ha), the spacing factor was high (45\%), this showing that the plantation was still open. Basal area was relatively low with an average of $5.12 \mathrm{~m}^{2} /$ ha (Table l).

Table I.

Dendrometric characteristics of the Acacia auriculiformis plantations in the different plant communities.

\begin{tabular}{|c|c|c|c|c|c|c|c|c|c|c|c|}
\hline Type of plant community & $\begin{array}{l}\text { Plantationage } \\
\text { (yr) }\end{array}$ & $\begin{array}{l}\text { Density } \\
\text { (N/ha) }\end{array}$ & $\begin{array}{l}\mathrm{Hg} \\
(\mathrm{m})\end{array}$ & $\begin{array}{l}\text { MAlH } \\
(\mathrm{m} / \mathrm{y})\end{array}$ & $\begin{array}{l}\mathrm{Hd} \\
(\mathrm{m})\end{array}$ & $\begin{array}{l}\text { MAlHd } \\
(\mathrm{m} / \mathrm{y})\end{array}$ & $\begin{array}{l}\mathrm{Dg} \\
(\mathrm{cm})\end{array}$ & $\begin{array}{l}\text { MAID } \\
(\mathrm{cm} / \mathrm{y})\end{array}$ & $\begin{array}{l}\mathrm{Dd} \\
(\mathrm{cm})\end{array}$ & $\begin{array}{l}\mathrm{S} \\
(\%)\end{array}$ & $\begin{array}{c}\mathrm{G} \\
\left(\mathrm{m}^{2} / \mathrm{ha}\right)\end{array}$ \\
\hline $\begin{array}{l}\text { Axonopus compressus - } \\
\text { Scleria depressa }\end{array}$ & 1 & $999 \pm 133$ & $3.7 \pm 0.4$ & - & $4.2 \pm 0.7$ & - & $2.6 \pm 0.4$ & - & $5.0 \pm 0.6$ & $77.7 \pm 15.6$ & $1.7 \pm 0.5$ \\
\hline $\begin{array}{l}\text { Dolichos argenteus - } \\
\text { Cassytha filiformis }\end{array}$ & 2 & $926 \pm 140$ & $6.2 \pm 0.8$ & $3.1 \pm 0.4$ & $7.0 \pm 0.9$ & $3.5 \pm 0.4$ & $6.2 \pm 0.9$ & $3.1 \pm 0.5$ & $9.6 \pm 1.9$ & $45.0 \pm 9.8$ & $5.1 \pm 2.2$ \\
\hline $\begin{array}{l}\text { Lophira lanceolata - } \\
\text { Annona senegalensis }\end{array}$ & 10 & $677 \pm 107$ & $14.0 \pm 0.8$ & $1.4 \pm 0.1$ & $16.8 \pm 0.7$ & $1.7 \pm 0.1$ & $12.5 \pm 1.0$ & $1.2 \pm 0.1$ & $18.8 \pm 0.4$ & $23.1 \pm 2.6$ & $12.3 \pm 1.1$ \\
\hline $\begin{array}{l}\text { Barteria nigritana - } \\
\text { Rauvolfia vomitoria }\end{array}$ & 13 & $533 \pm 150$ & $27.0 \pm 2.2$ & $2.1 \pm 0.2$ & $31.0 \pm 1.7$ & $2.4 \pm 0.1$ & $24.1 \pm 3.0$ & $1.9 \pm 0.3$ & $37.1 \pm 5.9$ & $14.3 \pm 1.9$ & $34.6 \pm 4.6$ \\
\hline
\end{tabular}

Note: Hg, Hd, Dg, Dd, S, MAIH, MAIHd, MAID, and G stand for mean height, dominant height, mean quadratic diameter, dominant diameter, spacing factor, mean annual increment in height, mean annual increment in dominant height, mean annual increment in diameter, and basal area, respectively. 
The heliophilous Lophira lanceolata and Annona senegalensis plant community was found on sandy soils in various topographic positions with very low slopes (mean slope $=1.31 \%$; SD $=0.64$ ). This tree plant community (photograph 4) that was dominated by the tree synusia of $L$. lanceolata and $A$. senegalensis, was associated with three widespread companion synusia: an annual one with Mitracarpus villosus and Perotis indica; a low perennial herbaceous of Mariscus alternifolius and Oldenlandia affinis; and a high perennial herbaceous of Andropogon gayanus and Andropogon tectorum. In this plant community, the basal area of the 10-year-old $A$. auriculiformis plantation (density $=677$ trees/ha) was quite low $\left(12 \mathrm{~m}^{2} / \mathrm{ha}\right)$ as well as the spacing factor (23\%) (Table I).

The Barteria nigritana and Rauvolfia vomitoria plant community was found at various topographic positions where slopes were generally low (mean $=1.04 \% \pm 0.81$ ). Soils were characterized by thin sands from 0 to $30 \mathrm{~cm}$, sometimes up to $40 \mathrm{~cm}$. Beyond this limit, silt appeared in the texture. Four other synusia were found besides the dominant one of Barteria nigritana and Rauvolfia vomitoria (photograph 5): the annual synusia of Asystasia gangetica and Phaulopsis angolana; a low perennial herbaceous synusia of Mariscus alternifolius and Oldenlandia affinis, a high perennial herbaceous synusia of Amorphophallus abyssinicus and
Sansevieria liberica; and the liana synusia of Opilia celtidifolia and Adenia lobata. Due to illegal logging, the density (533 trees/ha) of the 13-year-old $A$. auriculiformis plantation present in this plant community was relatively low, as compared to the initial density of 1111 trees/ha. The basal area was high (35 $\mathrm{m}^{2} / \mathrm{ha}$ ) while the spacing factor was low (14.3\%), revealing the high level of competition among trees in the stand since they had exceeded their optimal age of exploitation, which is approximately 8 to 10 years for the fast-growing species $A$. auriculiformis. The map of plant communities is presented on figure 3 .

\section{Floristic diversity of the plant communities}

\section{Species diversity}

The total species richness varied across the plant communities, and ranged from 11 to 138 . The Chromolaena odorata and Triumfetta pentandra community had the lowest species richness (11 species). By contrast, the plant community of Barteria nigritana and Rauvolfia vomitoria had the highest species richness (138 species). The species richness per phytosociological plot varied consistently according to the plant communities (at $P<0.001$ ). Likewise, the mean value of Shannon index ( $\left.H^{\prime}\right)$ per plot, as well as the mean value of Pielou evenness index, varied signifi-

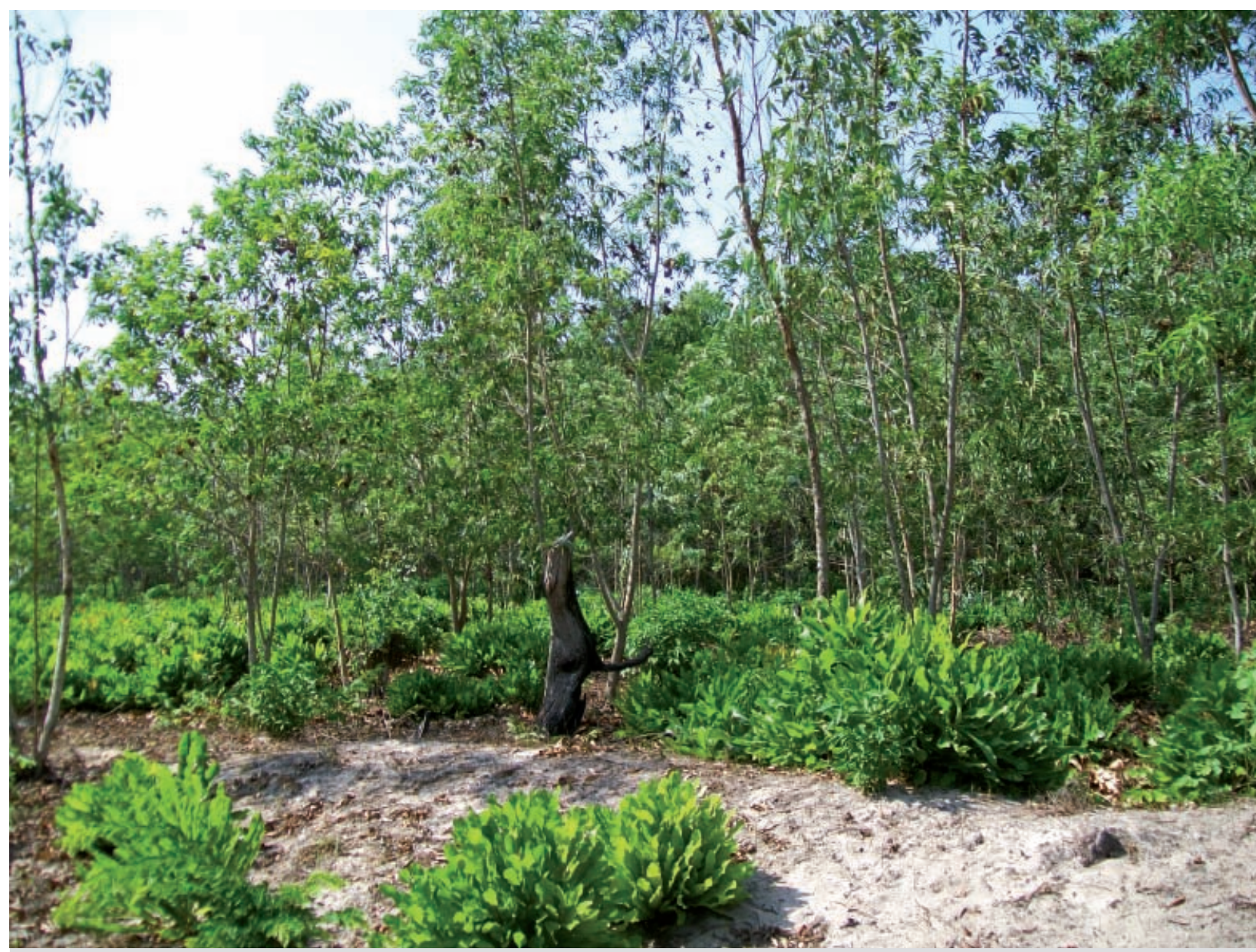

Photograph 4.

Lophira lanceolata and Annona senegalensis plant community, in the undergrowth of plantation. Photograph J. C. Ganglo. 
cantly (at P $<0.001$ ) with the plant communities (table II). Barteria nigritana and Rauvolfia vomitoria plant community was characterized by the highest species diversity per plot with respect to species richness, Shannon index, and Pielou evenness index. By contrast, Chromolaena odorata and Triumfetta pentandra plant community showed the lowest species diversity, whichever the parameter considered. Lastly Axonopus compressus and Scleria depressa plant community, Dolichos argenteus and Cassytha filiformis plant community, and the plant community of Lophira lanceolata and Annona senegalensis showed no significant difference with regard to species diversity parameters.

\section{Families and genera diversity}

Two hundred and forty-seven (247) species were found in the undergrowth of Acacia auriculiformis plantations in Pahou forest reserve. Regarding the distribution of those species across genera, there was also a wide dispersion. Two hundred and nine (209) genera were identified, $85 \%$ of which were represented by a single species. Only 31 genera were represented by at least two species (15\%). The most represented genera, with more than two species, were Albizia (4 species), Dioscorea (4 species), Mariscus (3 species), Phyllanthus (3 species), and Tylophora (3 species). Seventy-one (71) plant families were represented in the undergrowth of plantations in Pahou forest reserve. The number of species per family varied and ranged from 1 to 26. Twelve (12) families had at least 5 species, and six (6) of them had more than 10 species. These included Rubiaceae and Poaceae, the most represented families, with 24 and 23 species, respectively. The other families of the top six were Fabaceae (18 species), Cyperaceae (14 species), Euphorbiaceae (12 species), and Apocynaceae (11 species). As highlighted above for the distribution of plant species across genera, the noticeable picture is the low species richness within the majority of plant families. For example, 25 families were represented by only one species, and 22 were represented by two species. Therefore, $66 \%$ of the plant families inventoried during the study were represented by one or two species.

\section{Variation of plantation productivity across plant communities}

To describe the variation of plantation productivity within phytocoenoses, we only consider the plant communities that grew in the undergrowth of forest plantations, id est all phytocoenoses except the Chromolaena odorata - Triumfetta pentandra community. As shown in table III, the plantation productivity indices differed significantly (at $P<0.001$ ) according to the one-way analysis of variance. The Barteria nigritana - Rauvolfia vomitoria-community was the most productive with a productivity index of $18.7 \mathrm{~m}$ that was significantly higher than that of the three other phytocoenoses while the Lophira lanceolata Annona senegalensis (11.7 m) and Dolichos argenteus Cassytha filiformis, $(10.0 \mathrm{~m})$ communities had similar productivity levels according to the NeWMAN \& KeULS test at $5 \%$. The Axonopus compressus - Scleria depressa-community had the lowest productivity index with an average of $9.0 \mathrm{~m}$. Based on the results above, the forest site map of Pahou Forest reserve was elaborated (figure 4).

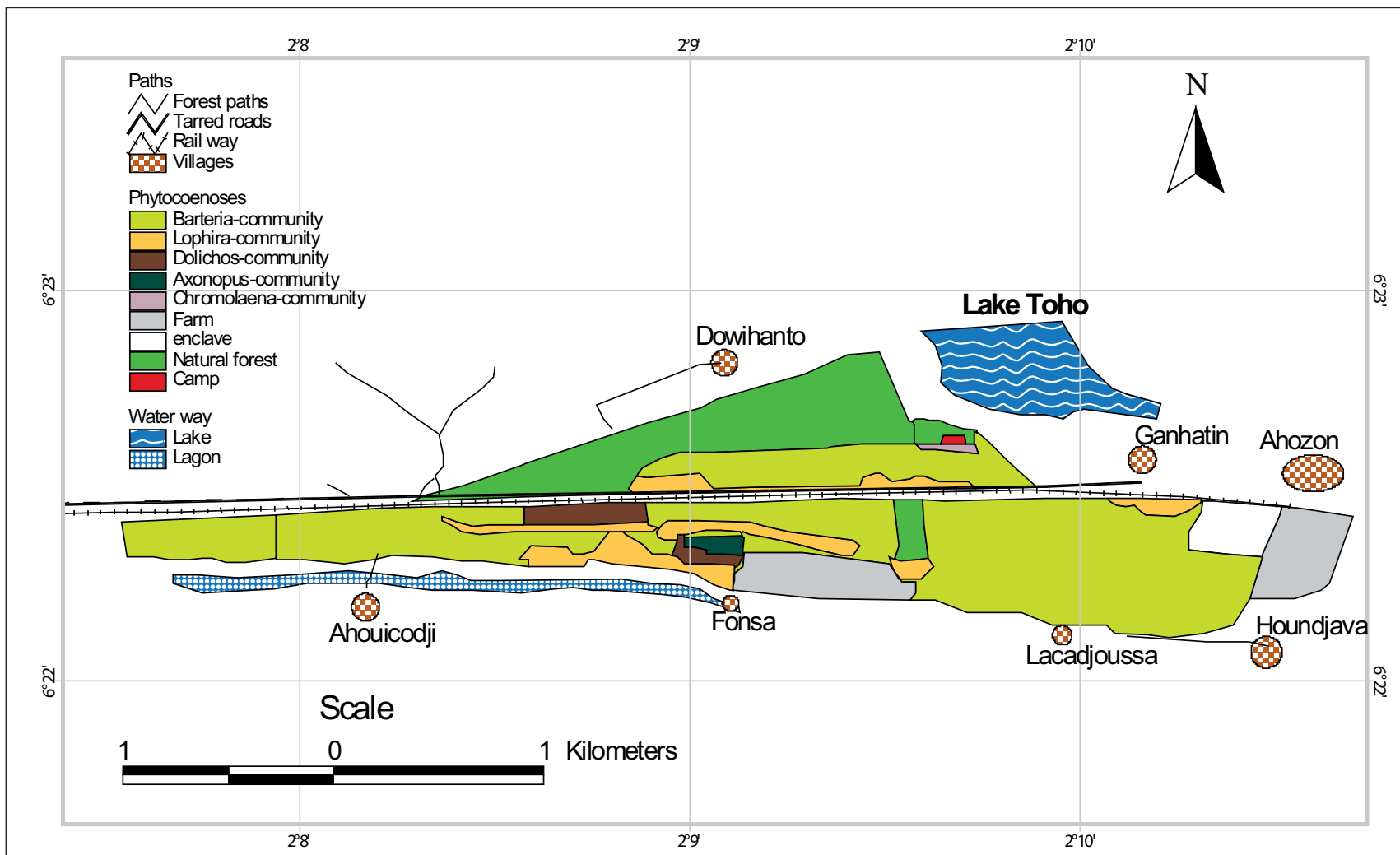

Figure 3.

Plant-communities identified in Pahou forest reserve. 


\section{Discussion}

\section{Floristic diversity of the understorey plant-communities}

The overall number of species per plant community ranged from 11 (Chromolaena odorata plant community) to 138 (Barteria nigritana and Rauvolfia vomitoria plant community). When the mean species richness per survey ( diversity) was considered, the same trend of species richness distribution according to plant communities is observed: 7 species per survey in Chromolaena odorata plant community to 49 in Barteria nigritana and Rauvolofia vomitoria plant community. The large and dense cover of Chromolaena odorata contributed to the exclusion of competitor species, and therefore reduced species diversity. From the observations, the biotope of Barteria nigritana and Rauvolfia vomitoria plant community was among the most productive of Pahou forest. It leads to deduce that soil fertility also contributed to species richness of plant-communities. The species richness of the plant communities of Pahou forest reserve is comparable to that of other undergrowth plant communities of Benin like in Lama forest (GANGLO, 2005) and largely higher than that observed in the understory vegetation of Eucalyptus and Pine plantations of Congo (N'Zala et al., 1997). The Shannon index and even- ness coefficient values of the plant communities of Pahou forest varied from 0.19 to 3.24 and 0.07 to 0.58 respectively. Chromolaena odorata plant community was also the least diversified plant community and Barteria nigritana and Rauvolfia vomitoria plant community the most one. The species abundance distribution in Pahou forest was not so balanced as compared to other situations in Benin (GANGLO, 2005). Apart from the Chromolaena odorata plant community, the species abundance was better balanced in Pahou forest as compared to Pine and Eucalyptus plantations of Congo where values of Shannon index and evenness coefficient of Pielou ranged from 0.26 to 0.45 and 0.24 to 0.45 respectively (N'ZALA et al., 1997).

\section{Dendrometric characteristics of the Acacia plantations}

Although A. auriculiformis plantations had different ages across the plant communities, comparisons can be made based on their annual height and diameter increments. At 13 year-old, the Acacia plantation in Barteria nigritana and Rauvolfia vomitoria plant community still had an appreciable mean annual increment in diameter and height, id est $1.9 \mathrm{~cm} /$ year and $2.1 \mathrm{~m} /$ year respectively, while in Lophira lanceolata plant community, the 10 yearold Acacia plantation was less productive with a mean

Table II.

Comparison of diversity parameters of plant-communities.

Plant communities

Chromolaena odorata - Triumfetta pentandra

Axonopus compressus - Scleria depressa

Dolichos argenteus - Cassytha filiformis

Lophira lanceolata - Annona senegalensis

Barteria nigritana - Rauvolfia vomitoria

\begin{tabular}{c|c|c}
$\begin{array}{c}\text { Total } \\
\text { species } \\
\text { richness }\end{array}$ & $\begin{array}{c}\text { Mean species } \\
\text { richness }(\alpha)^{\star}\end{array}$ & $\begin{array}{c}\text { Mean Shannon } \\
\text { index } \\
\text { per plot }\left(H^{\prime}\right)^{\star}\end{array}$ \\
11 & $7 \mathrm{~b}$ & $0.19 \mathrm{~b}$ \\
\hline 19 & $14 \mathrm{a}$ & $1.01 \mathrm{ab}$ \\
\hline 51 & $14 \mathrm{a}$ & $1.44 \mathrm{a}$ \\
\hline 93 & $17 \mathrm{a}$ & $1.23 \mathrm{a}$ \\
138 & $49 \mathrm{c}$ & $3.24 \mathrm{C}$
\end{tabular}

Mean value of Pielou equitability index per plot $(\mathrm{E})^{\star}$ $0.07 \mathrm{~b}$ $0.27 \mathrm{ab}$ $0.39 a$ $0.30 \mathrm{a}$ $0.58 c$

* Means followed by the same letter in a given column are not significantly different according to the Newman \& Keuls test at $P<0.05$.

Table III.

Variation of plantation productivity indices according to plant communities.

\begin{abstract}
Type of plant community
\end{abstract}
Axonopus compressus - Scleria depressa Dolichos argenteus - Cassytha filiformis Lophira lanceolata - Annona senegalensis Barteria nigritana - Rauvolfia vomitoria

$\begin{gathered}\text { Mean productivity } \\ \text { index }(\mathrm{m})^{\star}\end{gathered}$
$9.04 \pm 1.55 \mathrm{c}$
$10.97 \pm 1.37 \mathrm{~b}$
$11.67 \pm 0.49 \mathrm{~b}$
$18.68 \pm 1.01 \mathrm{a}$

$\begin{gathered}\text { Amplitude } \\ \text { of productivity } \\ \text { indices (m) }\end{gathered}$
3.75
3.23
0.52
2.67

\begin{tabular}{|c|}
\hline $\begin{array}{c}\text { Variation } \\
\text { coefficient (\%) }\end{array}$ \\
\\
\hline 17.14 \\
12.48 \\
4.19 \\
5.40
\end{tabular}

* Means \pm Standard Deviation of productivity indices followed by the same letters are not significantly different according to the Newman \& Keuls test at $P<0.05$. 
annual increment in diameter and height of $1.2 \mathrm{~cm} /$ year and $1.4 \mathrm{~m} /$ year respectively. In the 2 year-old Acacia plantation found in the Dolichos argenteus and Cassytha filiformis plant community, the mean annual increment in diameter and height were $3.1 \mathrm{~cm} /$ year and $3.1 \mathrm{~m} /$ year, respectively whereas the diameter and height of trees were $2.6 \mathrm{~cm}$ and $3.7 \mathrm{~m}$ respectively in the 1 year-old Acacia plantation found in the Axonopus compressus and Scleria depressa plant community. On the basis of a mean annual increment at 1 or 2 year-old, it is difficult to predict a reliable future performance of plantations. It can however deduce from the above comments that, overall, the Barteria nigritana - Rauvolfia vomitoria plant community was among the most productive of Pahou forest reserve although it was over aged and over dense. The over stocking of this plantation is also explained by the low value of the spacing factor, id est $14.3 \%$. The other plantations were relatively more open with spacing factor values ranging from 23 to $77 \%$. The Acacia plantations of Pahou forest are among the most productive in Benin according to other results obtained in Lama Forest in center Benin (FonTon et al., 2002). Their productivity is also of comparable to that of the most productive Acacia plantations in Asia based on the results obtained by HULIKATTI and MADIWALAR (2011) in Karnataka state (India) or by SAHRI et al. (1998) in Malaysia, Thailand and Indonesia.

\section{Ecological determinism of plant-communities}

The study of ecological factors in the phytocoenoses showed a relation between plant communities and site factors. The results agreed with those of ULLMANN et al. (1995) who studied the influence of environmental factors on road- sides verges in southern New Zealand where the floristic composition was correlated with the variation of environmental factors, such as rainfall, but also continentality, altitude, soil acidity and soil organic matter content. The results obtained by TANGHE (1969) in south-east Belgium clearly showed the importance of ecological factors (mainly topographic and edaphic) on the development of specific plant communities. The same observations were also made by DECOCQ (2000) in the high Oise valley in Belgium. Previous phytosociological studies in Benin also revealed the effects of topography, sunlight, and types of soils in the differentiation of plant communities (GANGLO et al., 1999; GANGLO, 2005; GAnglo, De Foucault, 2006).

\section{Management specifications}

Silvicultural practices and management activities must be based on the potentialities and constraints of forest sites identified. Hence, a specific management can be proposed for each plant community for a sustainable use of forest resources.

The Barteria nigritana-Rauvolfia vomitoria community, which was the most productive, would be adapted to high quality timber production with Tectona grandis, Terminalia superba, Triplochiton scleroxylon.... instead of firewood production as now. Silvicultural treatments must also favor regeneration and growth of native species usually found in this plant community, such as Pycnanthus angolensis, Antiaris toxicaria, Cleistopholis patens, Barteria nigritana, Diopyros soubreana or Dialium guineense. The Lophira lanceolata-Annona senegalensis phytocoenose is suitable for firewood production. In addition to A. auriculiformis, sil-

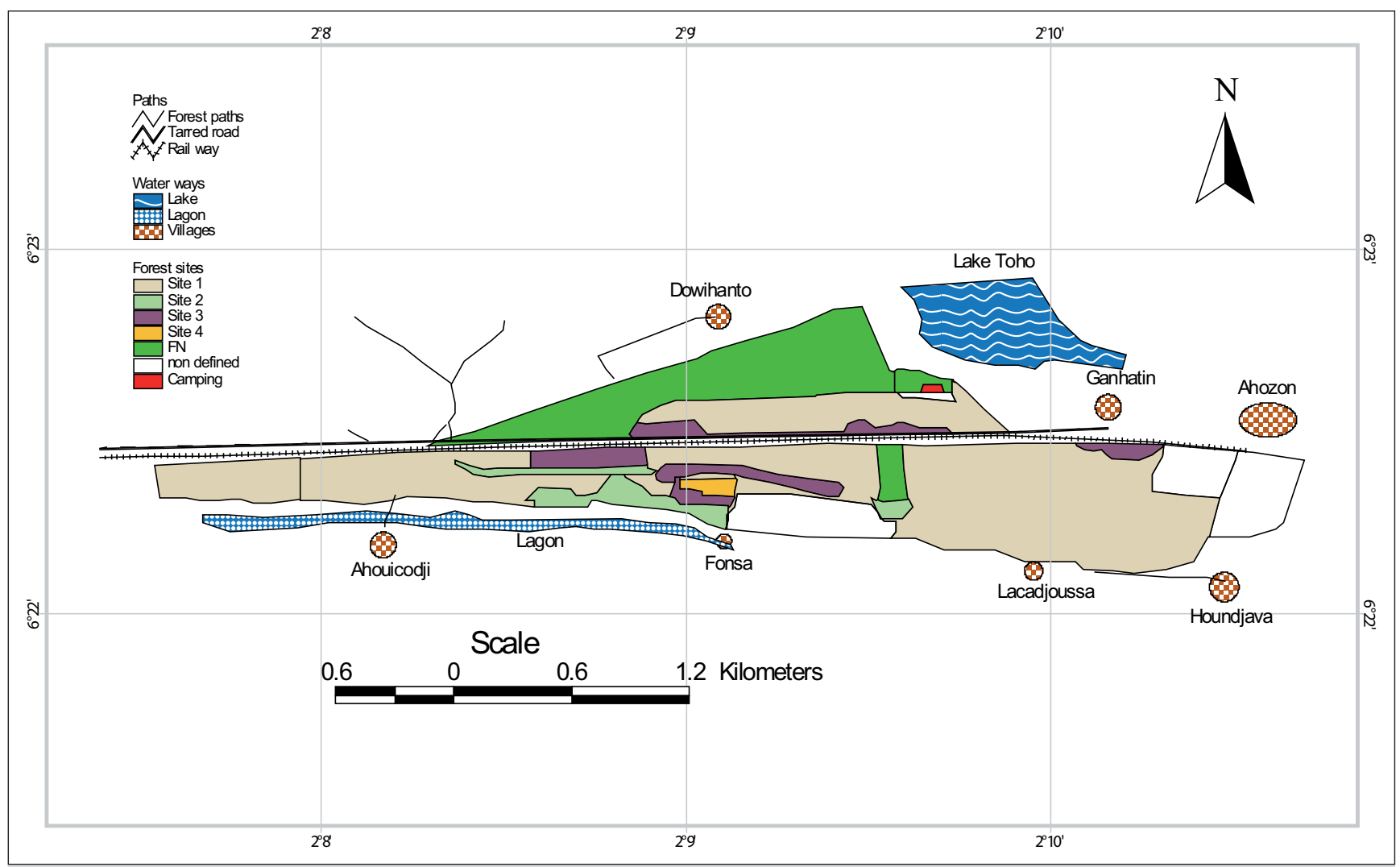

Figure 4.

Forest sites identified in Pahou forest reserve. 
vicultural treatments must take care of spontaneous plants naturally found in such difficult site conditions, especially Lophira lanceolata. The Dolichos argenteus-Cassytha filiformis community was not enough productive and thus should be used for firewood production, exempli gratia planting $A$. auriculiformis which could also improve the site and soil conditions. The Axonopus compressus-Scleria depressa community found in swampy sites was the least productive one. These sites could however be successfully used for Eucalyptus and Ceiba pentandra species which grew better than $A$. auriculiformis in such conditions. Nonwoody products could also be considered through garden crops and fruit-production.

The findings are useful to design adequate silvicultural treatments in many other forests of the country wherever the same plant communities are found.

\section{Conclusion}

In forestry, there are two ways to estimate forest productivity: the first one is the method of direct estimation of forest productivity based on total volume estimation of the forest or measurements of volume increments; the second method is that of indirect estimation of the productivity which consists of using ecological indices, mainly that of climates, soils, topography and plant communities. The results of the study are an illustration of the method of indirect forest productivity estimation. In that field, it have very few research works. Several of them showed a significant variation of productivity levels according to plant communities in a study on the productivity. This kind of studies carried out in many forests of the South and Center Benin by the end the 1990s were undertaken in order to find reliable forest management tools. This study in Pahou helped to describe five plant communities. The Barteria nigritana- Rauvolfia vomitoria plant community was the most diversified with respect to species richness and species abundance distribution. The productivity of the plantations found in the plant communities varied according to plant communities, and the highest productivity of Acacia plantations was recorded in the Barteria nigritana-Rauvolfia vomitoria plant community. In contrast, the lowest productivity of Acacia plantations was noted in the Axonopus compressus-Scleria depressa plant community. The Acacia plantations in Pahou forest are as productive as many others, mainly those in Thailand, Malaysia, Indonesia, and India. The findings are useful to design adequate silvicultural treatments in many other forests of the country wherever the same plant communities are found.

\section{Nota bene}

About 230 plant species were assessed across the various vegetal synusia of Pahou forest; details concerning them can be obtained from the main author of the article or asking for to the website of the Journal Bois et forêts des tropiques (bft-cirad.fr).

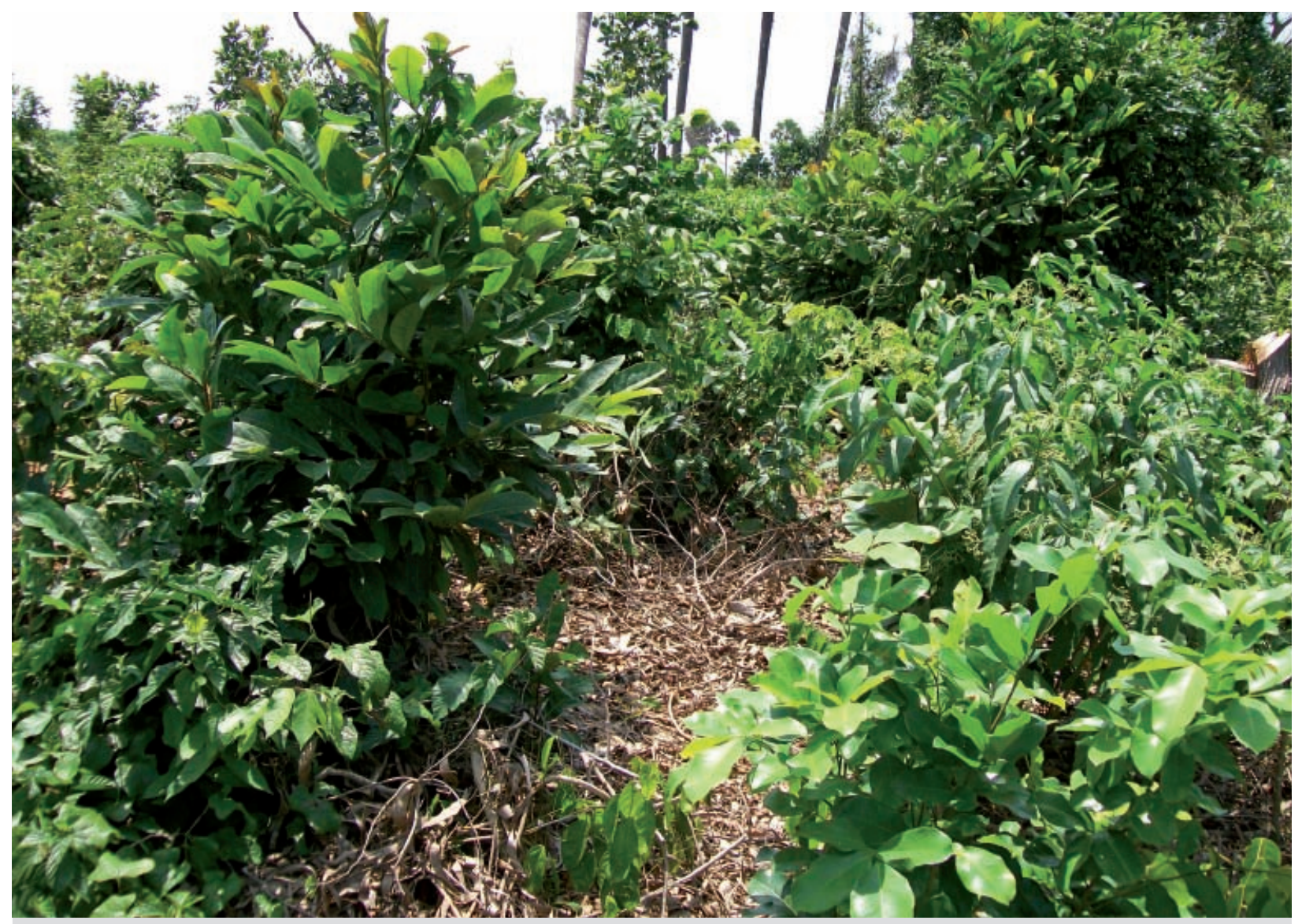

Photograph 5.

Barteria nigritana and Rauvolfia vomitoria plant community, regrowth after forest exploitation. Photograph J. C. Ganglo. 


\section{Acknowledgements}

These results were obtained thanks to the support of AIRESSud, a programme from the French Ministry of Foreign and European Affairs implemented by the Institut de Recherche pour le Développement (IRD-DSF).

\section{Bibliographical references}

AOUDJI A. K. N., GANGLO C. J., 2006. Phytosociologie appliquée à l'aménagement des forêts : cas du périmètre forestier de Pahou (Département de l'Atlantique, SudBénin). Journal de la Société botanique de France, 34 (3-5) : 89-92.

DAGNÉLIE P., 1956. Recherches sur la productivité des hêtraies d'Ardenne en relation avec les types phytosociologiques et les facteurs écologiques. Belgique, Bulletin de l'institut agronomique et des stations de recherches de Gembloux, 24 : 249-284; 369-410.

DAGNÉLIE P., 1957. Recherches sur la productivité des hêtraies d'Ardenne en relation avec les types phytosociologiques et les facteurs écologiques. Belgique, Bulletin de l'institut agronomique et des stations de recherches de Gembloux, 25 : 44-94.

DECOCQ G., 2000. La végétation forestière de la haute vallée de l'Oise (Belgique et France) : approche phytosociologique intégrée. Belgian Journal of Botany, 133 (1-2) : 5383.

FAO, 2001. Évaluation des ressources forestières mondiales 2000 - Rapport principal. Italie, Rome, Étude Fao, Forêt 140, 466 p. http://www.fao.org/forestry/fra/2000/ report/fr/

FAO. 2010. Global forest resources assessment 2010. Main report FAO Forestry paper 163, 378 p. http://www.ipex.org/ files/global_forest_resources.pdf

FONTON H. N., GLELE KAKAI R., RONDEUX J., 2002. Étude dendrométrique d'Acacia auriculiformis A. Cunn. ex Benth. en mélange sur vertisol au Bénin. Biotechnology, Agronomy, Society and Environment, 6 (1) : 29-37.

GANGLO C. J., LEJOLY J., PIPAR T., 1999. Le teck (Tectona grandis L. f.) au Bénin, gestion et perspectives. Bois et forêts des tropiques, 261 (3) : 17-27.

GANGLO C. J., 2005. Groupements de sous-bois, identification et caractérisation des stations forestières : cas d'un bois au Bénin. Bois et forêts des tropiques, 285 (3) : 35-46.

GANGLO C. J., DE FOUCAULT B., 2006. Plant communities, forest site identification and classification in Toffo reserve, South-Benin. Bois et forêts des tropiques, 288 (2): 25-38.

GILLET F., 2000. Phytosociologie synusiale intégrée. Guide méthodologique. $4^{\mathrm{e}}$ édition revue et corrigée. Université de Neuchâtel, 68 p.

GILLET F., DE FOUCAULT B., JULVE P., 1991. La phytosociologie synusiale intégrée : objets et concepts. Candollea, 46 : 315-340.
HULIKATTI M. B., MADIWALAR S. L., 2011. Management strategies to enhance growth and productivity of Acacia auriculiformis. Karnataka Journal of Agricultural Sciences, 24 (2) : 204-206.

HUTCHINSON J., DALZIEL J. M., 1954-1972. Flora of West tropical Africa. 3 volumes. Second edition by KEAY R. W. J. et HEPPER F. N. Crown Agents for Overseas Governments and Administrations. United Kingdom, London, Royal Botanic Garden.

LEBRUN J., 1947. La végétation de la plaine alluviale au Sud du lac Edouard. Publication IPN. Congo belge, 2 volumes.

LEBRUN J.-P., STORK A. L., 1991-1997. Énumération des plantes à fleurs d'Afrique tropicale. Vol. 1, 2, 3. Conservatoire et Jardin botaniques de la ville de Genève.

LOUMETO J. J., 1999. La végétation sous eucalyptus : cas des plantations de la région de Brazzaville au Congo. Le Flamboyant, 49 : 21-25.

MABIALA-MILONGUI A. L., 2003. Élaboration des courbes de productivité de l'Acacia auriculiformis dans les plantations de bois de feu au sud-Bénin. Thèse d'ingénieur des travaux, Collège polytechnique d’Abomey-Calavi. Bénin, Université d'Abomey-Calavi, $73 \mathrm{p}$.

NOUMON J. C., GANGLO J. C., 2005. Phytosociologie appliquée à l'aménagement des forêts : cas du périmètre forestier de Koto (Département du Zou, Centre-Bénin). Acta Botanica Gallica, 152 (3) : 421-426.

NOUMON J. C., GANGLO J. C., AZONTONDÉ A. H., DE FOUCAULT B., ADJAKIDJÈ V., 2009. Ecological and silvicultural indicatory value of plant-communities of the Koto forest reserve (Centre-Benin). International Journal of Biological and Chemical Sciences, 3 (2): 367-377.

N'ZALA D., NONGANAMI A., MOUTSAMBOTE J.-M., MAPANGUI A., 1997. Diversité floristique dans les monocultures d'eucalyptus et de pin au Congo. Cahiers de l'Agriculture, 6 : 169-174. RONDEUX J., 1993. La Mesure des arbres et des peuplements forestiers. Les Presses agronomiques de Gembloux, 521 p.

SAHRI M. H, ASHAARI Z., ABDUL KADER R., MOHMOD A. L., 1998. Physical and mechanical properties of Acacia mangium and Acacia Auriculiformis from different provenances. Pertanika Journal of Tropical Agricultural Science, 21(2): 73-81.

TANGHE M., 1969. Groupes écologiques, associations stationnelles et associations régionales des forêts du Sud-Est de la Belgique. Volume 1. Belgique, Thèse de doctorat, Université libre de Bruxelles, $148 \mathrm{p}$.

ULLMANN I., BANNISTER P., WILSON J. B., 1995. The vegetation of roadsides verges with respect to environmental gradients in southern New Zealand. Journal of Vegetation Science, 6: 131-142. 